\title{
Vozes da guerra, cantos de amor: um documentário-balada sobre meninos soldados
}

\author{
Miguel Alfonso Bouhaben, Sandra Straccialano Coelho \\ \& Guilherme Maia*
}

Resumo: O presente artigo tem como objetivo abordar sonoridades dos documentários realizados por Werner Herzog, a partir da análise de Balada do pequeno soldado (1984). Para tanto, se detém, mais especificamente, nos efeitos expressivos das diferentes musicalidades presentes no filme, assim como nas funções dialógica, plurilinguística e tradutora das diferentes vozes que habitam esse documentário.

Palavras-chave: som; documentário; realidade; música; vozes; ruídos.

Resumen: El presente artículo tiene como objetivo abordar sonoridades de los documentales realizados por Werner Herzog, a partir del análisis de Balada del pequeño soldado (1984). Para ello, se detiene, más específicamente, en los efectos expresivos de las diferentes musicalidades presentes en la película, así como en las funciones dialógica, plurilingüística y traductora de las diferentes voces que habitan ese documental.

Palabras clave: sonido; documental; realidad; música; voces; ruidos.

\begin{abstract}
This article addresses the sonorities of Werner Herzog's documentaries, based on the analysis of Ballad of the little soldier (1984). To do so, it focuses more specifically on the expressive effects of the different musicalities present in the film, as well as on the dialogical, plurilinguistic and translating functions of the different voices that inhabit this documentary.

Keywords: sound; documentary; reality; music; voices; noises.
\end{abstract}

* Miguel Alfonso Bouhaben: Escuela Superior Politécnica del Litoral. Universidad de las Artes de Ecuador, Facultad de Cine. 0901, Guayaquil, Equador. E-mail: mabouhaben@gmail.com

Sandra Straccialano Coelho: Universidade Federal da Bahia, Programa de PósGraduação em Comunicação e Cultura Contemporâneas (PósCom/UFBA), Bolsista PNPD-CAPES. 40130-000. Salvador (BA), Brasil. E-mail: sandrixcoelho@ gmail. com

Guilherme Maia: Universidade Federal da Bahia, Faculdade de Comunicação, Programa de Pós-Graduação em Comunicação e Cultura Contemporâneas. 41810-670, Salvador (BA), Brasil. E-mail: maia.audiovisual@gmail.com

Esta investigación fue desarrollada en el marco del Grupo de Investigación Cultura Visual, Comunicación y Decolonialidad (CUVICODE) y dentro del Proyecto de Investigación "Imagen y sociedad. La práctica audiovisual como forma de intervención social en América Latina" auspiciado por la Escuela Superior Politécnica del Litoral (ESPOL).

Submissão do artigo: 30 de maio de 2017. Notificação de aceitação: 13 de julho de 2017.

Doc On-line, n. 22, setembro de 2017, www.doc.ubi.pt, pp. 61-84. 
Résumé : Cet article vise à aborder les sonorités des documentaires de Werner Herzog, à partir de l'analyse de La ballade du petit soldat (1984). Pour ce faire, il se concentre plus précisément sur les effets expressifs des différentes musicalités présentes dans le film, ainsi que sur les fonctions dialogiques, plurilingues et de traduction des différentes voix qui habitent ce documentaire.

Mots-clés : son ; documentaire ; réalité ; musique ; voix ; bruits.

\section{Introdução}

Considerado por Deleuze como "o mais metafísico dos autores de cinema" (Deleuze, 1985: 208), Werner Herzog não apenas é responsável por uma farta produção documental, que remonta ao início de sua carreira, como tem se dedicado cada vez mais à realização de documentários, sobretudo nas últimas décadas. Dos 68 títulos em que é creditado como diretor no IMDB, ${ }^{1} 37$ são classificados como documentários, realizados tanto para o cinema quanto para a televisão, de acordo com durações distintas. Destes, observa-se que quase metade se localiza a partir dos anos 2000.

A despeito desse fato, o reconhecimento e posição conquistados por Herzog no campo cinematográfico dificilmente podem ser creditados aos documentários que produziu. Críticos e pesquisadores ainda têm se dedicado pouco à análise da vertente documental de seu cinema e, na maioria das vezes em que o fizeram, esta se viu convocada, quase sempre, em abordagens sobre aspectos autorais identificados em documentários específicos do cineasta alemão que obtiveram maior notoriedade, tais como Fata Morgana (1971) ou o mais recente $O$ homem urso $(2005),{ }^{2}$ por exemplo. Mais recentemente, e na contra-corrente dessa tendência, a coletânea organizada por Weinrichter \& Díaz (2007), assim como o livro de Eric Ames (2012), Ferocious reality: documentary according Werner Herzog, se propuseram a preencher essa lacuna.

A respeito, mais especificamente, da análise dos documentários de Herzog a partir de uma ótica autoral, Ames pondera que,

[...] the received idea about his body of work has been one of singularity and isolation, not unlike some of the figures in his movies. Clearly there is some truth to that idea, as far as it goes, which is one reason why Herzog's films are usually discussed in terms of auteurism. But a wholly appropriate emphasis on auteurism cannot account for the tenacity of his engagement with documentary. His intervention is strategic in the sense that it puts documentary in the service of enacting the director's personal style, as a way of emphasizing the alterity of his work, its diference from that of other filmmakers, its resistance to classification. But his intervention is also strategic in the sense

1. www.imdb.com/name/nm0001348/?ref_=fn_al_nm_1

2. Como exemplos de obras que analisam sob a perspectiva autoral o cinema de Herzog, e nas quais figuram análises de alguns de seus documentários, podemos citar a coletânea organizada por Corrigan (1986), assim como os livros de Nagib (1991; 2011) e Prager (2007). 
that it deliberately upsets documentary dogma. Herzog will never be a "good object" of documentary studies, at least not for scholars who are primarily concerned with politics, taxonomy, or purism. (Ames, 2012: 266).

Alinhados com esse posicionamento, mais especialmente com a ideia de que os documentários de Herzog costumam tensionar as fronteiras (por si só movediças) do cinema documentário, pretendemos, no presente artigo, abordar alguns dos aspectos sonoros dessa produção, não apenas por se tratar de um elemento muitas vezes negligenciado nas análises encontradas, mas justamente pelo fato de que a articulação peculiar orquestrada por Herzog em seus documentários entre as imagens e as vozes, ruídos e músicas (diegéticas e não-diegéticas), nos parece ser uma das linhas de força centrais deste tensionamento.

Para tanto, iremos nos deter na análise específica de tais elementos no documentário televisivo Balada do pequeno soldado, realizado em 1984 na Nicarágua, por Herzog e pelo foto-jornalista Denis Reichle, e cujo tema é o treinamento de crianças da etnia indígena Miskito para lutarem contra os sandinistas. No entanto, antes de discorrer sobre esse filme mais especificamente, assim como sobre as razões que fundamentaram essa nossa escolha, é preciso que nos detenhamos, ainda que brevemente, sobre alguns dos elementos sonoros característicos dos documentários realizados por Herzog.

\section{Vozes, músicas e ruídos nos documentários de Herzog}

Em seus primeiros documentários, como Fata Morgana (1971) e O país do silêncio e da escuridão (1971), mas também em produções posteriores como Os sinos do abismo: fé e superstição na Rússia (1993) ou no mais recente $O$ diamante branco (2004), é possível observar alguns elementos recorrentes no que diz respeito ao plano sonoro nos documentários de Herzog e sua relação com as imagens. Dentre eles, o que primeiro nos chama a atenção é, sem dúvida, o comentário que o próprio diretor faz questão de gravar e sobrepor a estas, adotando procedimentos que se pode considerar não tão usuais no gênero, seja pela própria tonalidade caraterística de sua voz, distante de um padrão de locução "profissional", seja pela recorrência com que traduz (em alemão ou em inglês, com forte sotaque) as falas dos personagens filmados, sobrepondo sua voz à deles com frequência, em detrimento da utilização de outros recursos possíveis como o da legendagem, por exemplo.

A respeito de sua escolha por ser o comentarista de seus filmes, mesmo nos casos em que a locução foi realizada em inglês, Herzog afirmou em uma entrevista: 
In my 'documentaries' you will often hear my voice. One reason for this is that I would rather audiences who do not understand German listen to my voice in English rather than hear me in German and read the subtitles. I think the result is a stronger connection to what I originally intended for the film. I have also never liked the polished and inflected voices of those overly trained actors. (Herzog apud Nagib, 2011: 77; grifo nosso).

A afirmação do diretor alemão é no mínimo curiosa, pois ao mesmo tempo em que demonstra uma opção crítica e consciente por se distanciar de um certo estereótipo que costuma caracterizar a chamada "Voz de Deus" no documentário, revela, simultaneamente, o desejo de controlar os significados apreendidos pelo espectador. Dessa aparente contradição surge um dos traços talvez mais marcantes dessa sua produção, na qual, mesmo que diferentes vozes sejam convocadas, Herzog parece sempre querer garantir para si a última palavra, o que traz à tona questões éticas fundamentais do próprio gênero documental, além de oferecer munição para parte da crítica que vê na faceta documentarista de Herzog um exemplo problemático (enquanto outros podem identificar, nesse mesmo traço, provavelmente sua originalidade e maior contribuição pessoal).

Também podemos observar que o uso dos ruídos e da música é feito de forma expressiva e pouco convencional pelo diretor em seus documentários. ${ }^{3}$ Afastando-se de uma estética pretensamente naturalista, Herzog parece convocar tais elementos sonoros para criar efeitos variados, os quais vão desde a tentativa de expressar aspectos intangíveis da realidade - como no caso do retrato da experiência de cegos-surdos em $O$ país do silêncio e da escuridão, ou da tentativa de encenar aspectos da fé religiosa russa em Sinos do Abismo-, à criação de unidades audiovisuais claramente dissonantes e perturbadoras do ponto de vista da experiência espectatorial. Um exemplo evidente desse efeito perturbador pode ser observado na sequência de abertura do documentário televisivo Wodaabe: herdsmen of the $\operatorname{sun}^{4}$ (1989), na qual o cineasta sobrepõe uma versão da Ave Maria de Gounod às imagens "extravagantes" de dançarinos fulani que vivem no deserto do Saara, desafiando as expectativas daqueles que poderiam esperar desse filme um relato audiovisual etnográfico clássico para, ao invés disso, criar um claro efeito de justaposição cultural, como bem observa Ames a respeito desse filme:

Herzog also stages his own cultural diference - and does so primarily by means of asynchronous music and his use of vocal presence - as if it were

3. Não nos deteremos nesse artigo sobre a produção ficcional do cineasta, contudo vale registrar que a música é um elemento que se destaca na produção de Herzog de maneira geral, seja ela ficcional ou documental.

4. www.youtube.com/watch?v=MlnO1QDqpaQ 
Vozes da guerra, cantos de amor: um documentário-balada sobre meninos soldados

the only way he could acknowledge diference as internal to the project of representing others. (Ames, 2012: 45).

Contudo, defendemos aqui que não é apenas no uso da música extradiegética que Herzog encontrou recursos para a criação audiovisual desse efeito de diferença cultural, ou mesmo para o estabelecimento de seu lugar de singularidade com relação a um certo paradigma documental. Foi também ao encenar as sonoridades e músicas locais de culturas não-europeias que o diretor alemão explorou, em seus documentários, os efeitos emocionais, de distanciamento e mesmo de desconforto espectatorial que parecem caracterizar esse espectro da sua filmografia, como tentaremos demonstrar, a seguir, por meio da análise das sonoridades presentes em Balada do pequeno soldado.

Realizado com Denis Reichle, que já trabalhava para jornais como Paris Match e Der Spiegel em varias áreas de conflito coloniais no período (e que foi o primeiro idealizador do projeto de realizar um filme sobre as "criançassoldado" entre os Miskitos), esse filme pouco conhecido da filmografía herzogiana é identificado por alguns autores como um ponto estratégico na carreira do diretor alemão, especialmente por ter sido lançado dois anos após a polêmica em torno das filmagens de Fitzcarraldo ${ }^{5}$. Ames considera que esse filme estaria estreitamente vinculado a uma tentativa de resposta do cineasta às inúmeras críticas sofridas na ocasião. Já para outros, como Nagib (2011: 113), trata-se, pelo contrário, de uma das poucas vezes em que Herzog se colocou no campo documental a partir de um posicionamento intencionalmente político.

Contudo, não está no escopo de nosso trabalho ajuizar a respeito de mais essa polêmica em torno do cinema de Werner Herzog, mas apenas registrar o fato de que, assim como o restante de sua produção documental, Balada do pequeno soldado suscitou igualmente críticas e elogios, os quais, na nossa leitura, em muito se vinculam às ambiguidades que caracterizam os documentários desse cineasta. Grande parte delas, como pretendemos demonstrar a seguir, se encontram arquitetadas, sobretudo, pela articulação peculiar entre a voz do diretor e a dos personagens por ele filmados, assim como pela utilização característica dos demais elementos sonoros presentes nesses filmes, notadamente das músicas e da forma como estas são utilizadas junto às imagens.

5. Com duração de aproximadamente quatro anos, a produção turbulenta e pouco ortodoxa do filme contou com vários acidentes entre os membros da equipe, além de rebeliões por parte de indígenas insatisfeitos com as condições de trabalho. A lenda em torno das filmagens conta ainda com a proposta do assassinato de Klaus Kinski que foi feita pelos indígenas a Herzog, frente aos frequentes ataques de cólera do ator. 


\section{Das sonoridades em Balada do pequeno soldado}

Passemos agora ao exercício analítico da obra, com o objetivo de apresentar nossas apostas interpretativas sobre o modo como as canções, os ruídos e as vozes operam no jogo audiovisual de Balada do pequeno soldado. Examinaremos mais detidamente 3 aspectos. O primeiro, busca entender de que forma as canções do filme se articulam com os fluxos de tensão e distensão da narrativa. O segundo aspecto que julgamos relevante é o papel das canções e dos ruídos na estrutura formal da película. Por fim, colocamos em foco, sob uma perspectiva decolonialista, alguns aspectos das vozes que falam na trilha sonora.

\section{Cantos dos pequenos soldados: compaixão, alívios líricos e amores ausentes}

O jogo audiovisual inicia com um plano conjunto de um menino sentado, vestido de farda militar e segurando uma metralhadora, na ação de apertar um botão no gravador cassete que está em quadro ao lado dele. Uma canção começa a ser tocada no aparelho e ele canta junto. $\mathrm{O}$ eu lírico da canção ${ }^{6}$ é um menino em idade escolar que está enamorado de uma colega de classe. Ele está triste porque ella de la mochila azul, la de ojitos dormilones, não está mais indo às aulas. Uma canção triste sobre um menino que vê despertar em si o amor por uma menina que está ausente. Importa saber que a voz que canta no aparelho é a voz de uma criança. A canção que estamos ouvindo é uma gravação de "La de la mochila azul", composta pelo compositor mexicano Bulmaro Bermúdez e gravada pelo também mexicano "menino prodígio" Pedrito Fernandez, quando tinha apenas 7 anos. Essa canção romântica obteve um grande êxito radiofônico e televisivo internacional entre as crianças da América hispanohablante na virada da década de 1970 para a de 1980 e gerou 2 longas-metragens com o menino Pedrito Fernandez como protagonista:

6. Que te pasa chiquillo, que te passa / Me dicen en la escuela y me preguntan en mi casa I Y hasta ahora lo supe de repente / Cuando vi pasar la lista y ella no estuvo presente / Ella de la mochila azul / la de ojitos dormilones / Me dejo gran inquetud / Y bajas calificaciones / Ni al recreo quiero salir / No me divierto con nada / No puedo leer ni escribir / Me hace falta su mirada / De recuerdo me quedan sus colores / Dos hojas del cuaderno dice amores entre borrones / Yo quisiera mirarla en su pupitre / Porque si ella ya no vuelve mi salon sera muy triste.

O que está havendo, meu pequeno? / O que você tem? / Dizem para mim na escola / E me perguntam lá em casa / E agora, de repente eu sabia / Quando passou a lista de presença / Ela não estava presente / Aquela da mochila azul / Com seus olhinhos sonhadores / Por ela perdi minha calma / E as notas pioraram / Não saio para o recreio / Nada me diverte / Não sei ler nem escrever / Sinto falta do seu olhar / De lembrança ficaram seus lápis de cor / Duas folhas do seu caderno / Onde está escrito amor / Queria vê-la no seu banco da escola / Porque se ela não voltar / Minha sala será triste / Aquela de mochila azul (transcrição das legendas). 
Vozes da guerra, cantos de amor: um documentário-balada sobre meninos soldados

La niña de la mochila azul (1979) e La niña de la mochila azul 2 (1981), ambos dirigidos por Rubén Galindo.

Durante toda a primeira exposição integral da letra e da melodia, o plano conjunto fixo nos permite perceber uma expressão triste do pequeno soldado adequada, aliás, à natureza sentimental da canção. O olhar inquieto dele, que ora mira o espectador, ora parece mirar para alguém da equipe, ou, ainda, parece olhar para o vazio, nos faz parecer que ele não está muito à vontade diante da câmera e da situação. O plano nos mostra também um jogo metafórico que explora a similaridade entre o modo como o menino segura a metralhadora e o modo como se segura um violão (em alguns momentos, o menino parece até "dedilhar" a empunhadeira da metralhadora). No início da reexposição da letra, o pequeno soldado armado cresce no quadro e chegamos mais perto de sua expressão triste. Um corte passa a nos mostrar outros meninos, igualmente fardados e armados, entrando em formação militar. Dois deles olham para a câmera com expressão de desconfiança. Outro corte nos traz de volta ao pequeno soldado que canta. Após ser apresentada na sua integralidade, ou seja, após ouvirmos o fonograma completo sem supressão de seções e sem saída em fade out, a canção "La de la mochila azul" declara o seu ponto final. A seguir o vemos desligar o gravador, em plano detalhe, e a tela nos deixa com um plano próximo do menino em silêncio por mais algum tempo. O semblante triste se abre em um sorriso radiante. Durante alguns segundos, ele parece estar sorrindo para o diretor do filme ou para alguém que está no set de filmagem. Em seguida, olha para nós, espectadores. Aos poucos, o sorriso desaparece da boca, mas permanece no olhar. Fim da seção de abertura do filme. A imagem que inaugura o próximo segmento é um close-up de uma menina sorrindo.

Para utilizar um conceito famoso esculpido por Michel Chion (2011), nos perguntamos que espécie de contrato audiovisual o filme deseja oferecer ao espectador nesta cena de abertura? De que modo o filme pretende que o espectador seja afetado pela justaposição da imagem de um menino fardado, de olhar inquieto, segurando uma metralhadora grande demais para o tamanho dele, com a sonoridade de uma canção romântica que chora dores de primeiros amores em vozes infantis? Que tipo de discurso esta audiovisão tão insólita e ambígua prenuncia? Seria somente aquilo que Nagib (2011) chamou de "permanent search for primacy", a busca constante por "images and sounds that were never seen or heard before" (p. 85), que caracterizam a obra de Herzog, de uma maneira geral?

Nossa aposta interpretativa, de certa forma, vai ao encontro do que Ames afirma em relação ao design de canções do filme que estamos analisando: 
Ballad of the Little Soldier consists largely of folk songs and native testimonies. Together, they give voice - indeed, a chorus of voices - to the victims of atrocities against native peoples past and present. The singing of love songs, in particular, evokes at once the pleasures of living and the tragedy of child soldiers who might not live so long as to enjoy such experiences. (Ames, 2012: 161).

O filme contém, de fato, um exemplo daquilo que Ames chama de folk songs, uma "canção de amor" da tradição oral dos miskitos, mas as canções com maior tempo de tela e maior potência expressiva na obra - abertura e final - utilizam repertório de sucessos da canção popular massiva latino-americana produzida no México. A outra canção também não é exatamente uma folk song, mas uma canção utilizada em práticas rituais católicas, composta "para cantar en una bienvenida de un retiro o en un popurri de inicio". 7 O que nos interessa na afirmação de Ames, contudo, é a menção à tensão entre o prazer de viver e a trágica perspectiva de morte prematura que as love songs evocam.

O que vemos e ouvimos não é uma manifestação espontânea do real capturada pela câmera e pelos gravadores. Ao contrário, estamos diante de uma situação claramente encenada. Nossa aposta interpretativa é que essa espécie de "número musical" encenado abre o filme oferecendo ao espectador, em uma chave poética e metafórica, boas pistas sobre a questão central da obra. Amor e guerra, infância e morte. São pré-adolescentes que tiveram seus laços familiares dilacerados por massacres e estão sendo treinados para matar ou morrer nas selvas da América Central. Desde o seu primeiro passo, o filme busca construir uma aderência afetiva e solidária entre nós, espectadores, e aquelas crianças que vamos conhecer ao longo da narrativa.

Se na dimensão do conteúdo, o que se ouve e o que se vê tem quase sempre um caráter trágico - relatos de genocídios; de violência extrema; de perda de mães, pais e irmãos; crianças pré-púberes sendo treinadas para matar e morrer - as canções utilizadas no filme são signos que apontam para outras direções. A segunda exposição de uma canção ocorre quando vemos soldados miskitos regressarem de uma missão. Eles são recebidos por um alegre canto coletivo de boas-vindas. Vemos muitas crianças, majoritariamente meninas, cantando uma canção da liturgia católica que, em sua frase conclusiva diz: dame la mano y mi hermano serás. ${ }^{8} \mathrm{O}$ encontro é uma confraternização festiva, ve-

7. Fontes: Cancioneiro Católico (http://musicatolica.me/cancionerocatolico/Song/2939/D AME\%20LA\%20MANO.html , lacuerda.net https://acordes.lacuerda.net/musica_religiosa/da me_la_mano_y_mi_hermano_seras.shtml

8. No me importa de todo tú seas / si detrás del Calvario estás / Si tu corazón es como el mío / dame la mano y mi hermano serás / CORO/ Dame la mano, dame la mano, dame la mano y mi hermano serás (bis) / No importa la raza que seas / pobre o rico Cristo te amará / Si tu corazón es como el mío / dame la mano y mi hermano serás / CORO / No importa el sitio que vengas / pueblo o campo, todo es igual / Si tu corazón es como el mío / dame la mano y mi 
Vozes da guerra, cantos de amor: um documentário-balada sobre meninos soldados

mos crianças que cantam sorrindo, pessoas trocando abraços e apertos de mão. $\mathrm{O}$ filme concede cerca de um minuto e quarenta segundos de tempo de tela e de alto-falantes para mostrar ao espectador signos de amizade, identidade, solidariedade e afeto.

A terceira canção é antecedida pelo comentário de Herzog, que se sobrepõe às imagens:

- Aqui é Tapamlaya, bem perto da fronteira [com Honduras] (...) Tudo o que filmamos aqui durante os primeiros 20 minutos foi improvisado e sem plano algum. Primeiro seguimos a música. ${ }^{9}$

Corta para um primeiríssimo plano de um homem cantando uma canção em língua indígena. Logo a seguir, a música decresce para plano-de-fundo e ouvimos de novo a voz do narrador:

- Mais tarde perguntamos pela letra... uma canção de amor.

A música volta a ocupar o primeiro plano da trilha sonora e vemos claramente a alegria do intérprete. Mesmo considerando os olhares desconfiados que alguns meninos dirigem ao espectador, os sorrisos que vemos na tela nos permitem afirmar que estamos novamente diante de uma situação de "alívio lírico" em relação ao caráter cruel dos fatos que vinham sendo narrados pelo documentário. Mais uma vez, a canção é apresentada na sua integridade, no plano diegético e em uma situação que tem um razoável grau de encenação. Mais uma vez, um "número musical". Mais uma vez, tal como na cena inicial, estamos diante de um jogo metafórico entre amor e ódio, paz e guerra, vida e morte.

Depois desse terceiro número musical, a canção só volta ao filme na última cena. ${ }^{10}$ Em seu ponto final, o filme opta por voltar da capo, ou seja, voltar ao início. Um outro menino, também fardado e segurando uma metralhadora, canta Flor de las flores, um corrido norteño mexicano que era, no período das filmagens, um sucesso internacional no mundo hispanohablante, interpretado pelo grupo Los Cardenales de Nuevo Leon. O eu lírico da canção diz:

Flor de las flores, flor de mi amor

Vente conmigo y dame tu amor

Vuelve bien de mi vida

La dueña de mis amores

Ven y ven flor de las flores

hermano serás / CORO / Oh, hermano, juntemos las manos / y unidos vamos a luchar / Si tu corazón es como el mío dame la mano y mi hermano serás. / CORO

9. Tradução das legendas.

10. Antes disso, contudo, há algumas ocorrências importantes na poética sonora do filme que merecem alguma consideração e serão discutidas na próxima subseção deste artigo. 


\section{Ven a hacerme feliz}

Se por casualidade ou por conta de um rigor obsessivo da instância que tomou as decisões sobre as canções do filme, é difícil dizer. $\mathrm{O}$ fato fílmico, contudo, é que as canções que abrem e fecham as cortinas do espetáculo falam de amor, mas, sobretudo, de um amor ausente. A "ausência", é sem dúvida, uma das temáticas do filme, que nos conta histórias sobre perdas de familiares e, principalmente, sobre a ausência da infância. Assim como na cena de abertura, fica evidente, no fechamento do discurso, uma estratégia passível de ser interpretada como meio de mover os sentimentos do espectador em direção a uma inevitável ternura pelo pequeno soldado que canta dores de amores ausentes. Ternura que nos conduz, inexoravelmente, à compaixão. Os dois últimos rostos que o filme nos mostra, após a conclusão da canção, são rostos em primeiríssimo plano de duas crianças que sorriem para o espectador. Ao menos a julgar pelo design de canções do filme, nossa análise parece soar em consonância perfeita com as palavras proferidas por Herzog em entrevista, respondendo àqueles que criticaram o filme pela ausência de posicionamento político nítido: "it does not matter what political content there is when you have a nine-year-old fighting in a war. Child soldiers are such a tragedy that you do not need every single detail of the conflict"(apud Ames, 2012: 159).

\section{Um filme-balada?}

Ao nos depararmos com o título da obra, uma inevitável pergunta emerge: por que "balada"? Teria Herzog utilizado estratégia semelhante àquela utilizada por Ingmar Bergman em Sonata de outono? O filme de Bergman tem sua narrativa estruturada de modo rigorosamente análogo à Forma Sonata, modelo de composição musical dominante durante grande parte do período clássicoromântico. Como veremos, Balada de um pequeno soldado, em sua dimensão formal, estabelece vínculos com a balada medieval.

Para seguir nessa via de análise, em primeiro lugar temos que definir o conceito, a temática e a estrutura formal da balada medieval. Com relação ao conceito, podemos partir das contribuições de Albert B. Friedman (1961: 2), que considera a balada como "aliteratura" ou literatura analfabeta, devido a seu caráter oral. F. J. Child sublinha essa questão e afirma que a balada, stricto senso, é popular e tem que se descontaminar de elementos literários. Tomando essas considerações para fins interpretativos, podemos nos questionar se o filme de Herzog reivindica um caráter primitivo, popular e oral em sua proposta documental. Parece que o diretor alemão busca certa "pureza" além das formas literárias, tendo em vista que opta por abrir e fechar o filme 
Vozes da guerra, cantos de amor: um documentário-balada sobre meninos soldados

com canções populares do repertório cursi mexicano, ou seja, com um regime melódico e lírico que costuma ser preconceituosamente associado a certo maugosto das classes populares.

Ao se debruçar sobre a obra do cineasta alemão em Werner Herzog: o cinema como realidade, Nagib (1991) aponta elementos que parecem apoiar essa interpretação. A respeito do impulso reiterado do diretor que o levou, desde muito cedo em sua carreira, a romper com as barreiras do país natal, em busca de paisagens e povos de diferentes regiões do planeta, a autora afirma:

Sabemos que a proposta do diretor não é imobilista. Ao contrário, teve como germe escapar à estagnação em que se encontrava o cinema na Alemanha. [...] O primeiro passo do jovem cineasta foi romper as fronteiras do seu país, para encontrar fora dele a imagem inédita, antes nunca vista, e construir um cinema essencialmente de revelação. (Nagib, 1991: 171).

Ainda que, na análise de Nagib, essa busca de Herzog seja identificada em paralelo com o dilema do artista moderno face ao esgotamento da capacidade criativa, e que se traduziria, no cinema de Herzog, pela busca da "imagem inédita", pensamos ser possível convocar, nessa mesma chave interpretativa, os aspectos sonoros e musicais articulados em sua cinematografia. Em Balada do pequeno soldado, no que diz respeito mais especificamente ao paradigma da balada medieval que ora convocamos para a análise, nos parece possível traçar um paralelo entre essa busca, identificada pela pesquisadora brasileira como uma marca do cinema de Herzog, e certo caráter primordial que estaria inscrito na caracterização do próprio gênero medieval segundo os autores citados.

Sobre o modo de contar histórias das baladas medieivais, Miyares (2009) afirma:

la verdadera balada es breve, con transiciones abruptas entre episodios, sin llegar a contar toda una historia, pero siempre coherente: la acción no suele estar localizada puntualmente; y tiende a omitir tanto descripciones como explicaciones; su estilo es sencillo y llano (...) no usa palabras cultas (...) la extravagancia, el cinismo, la sofisticación, el refinamiento y la trivialidad no le son propias. (Miyares, 2009: 13).

Ao passo que Hodgart entende que "la técnica de montaje propia de las baladas, que presentan la narrativa no como una secuencia continua de acontecimientos, sino como una serie de instantáneas rápidas y su arte reside en la selección y yuxtaposición de esas imágenes" (Hodgart, 1962: 29). Já do ponto de vista temático, Rojas (2016: 20) explica: "la cuestión de la temática, a diferencia de lo que sucede con las "canciones", es mucho más variada, y por tanto es corriente que aborde temas de órdenes diferentes: políticos, sociales, históricos, amorosos, etc.". 
A partir do que nos diz Rojas, ou seja, entendendo a balada como um gênero sem tema fixo ou conjunto homogêneo de temas, não é possível estabelecer um vínculo de natureza temática entre o filme de Herzog e a balada medieval. Já no que diz respeito ao que Miyares afirma sobre "a verdadeira balada", e ao que Hodgard chama de "técnica de montagem" da balada, podemos observar analogias. O filme não nos conta uma história como uma sequência contínua de acontecimentos; omite descrições e explicações; é um filme breve e, podemos dizer, um filme com linguagem "simples", que evita a "extravagância" e as "palavras cultas".

Para examinar mais detidamente os aspectos formais da obra, na pista de uma possível analogia com a forma da balada medieval, é preciso assinalar que este gênero de poesia cantada surge na Europa no século XIV e que sua estrutura narrativa tem a singularidade de repetir um mesmo verso - o estribilho - a cada três estrofes. Esse elemento repetitivo é uma das marcas estilísticas que caracterizam essa forma poética: "la balada, como muchas otras formas medievales, también se basa en un elemento repetitivo, un estribillo introducido al final de cada una de las estrofas" (Rojas, 2016: 20). Podemos observar como a estrutura da balada medieval se ajusta, em alguns pontos, com a estrutura narrativa de Balada do pequeno soldado. Se relacionamos as estrofes com as cenas, e os estribilhos con as canções e com o que aqui chamamos de "números sonoros", ${ }^{11}$ podemos então configurar o seguinte esquema:

\begin{tabular}{llc}
\hline \multicolumn{2}{c}{ PRIMEIRO BLOCO } \\
\hline 1. Estribilho & Pequeno soldado canta “La de la mochila azul”. & 00:00 a 03:06 \\
2. Estrofe & Apresentação dos Miskitos & 03:07 a 04:46 \\
3. Estrofe & Acampamento do Misura. & 04:47 a 05:50 \\
4. Estrofe & O exército no Rio Coco e o desembarque. & 05:51 a 06:45 \\
5. Estrofe & O exército na selva & $06: 46$ a 07:55 \\
6. Estrofe & Exército novamente em marcha & $07: 56$ a 09:00 \\
\hline & \multicolumn{1}{c}{ SEGUNDO BLOCO } \\
\hline 7. Estribilho & Canto coletivo "Dame la mano, hermano" & $09: 01$ a 10:42 \\
8. Estrofe & Soldados conversando com as mulheres & $10: 43$ a 11:55 \\
9. Estrofe & Mulher relata como os Sandinistas a roubaram & $11: 56$ a 13:27 \\
10. Estrofe & O povoado de Sang Sang & $13: 28$ a 14:49 \\
11. Estrofe & Relato de um soldado adulto sobre o sucedido & $14: 50$ a 16:39 \\
12. Estrofe & Tapamlaya, campo de refugiados & $16: 40$ a 18:09 \\
\hline
\end{tabular}

11. Mais adiante, falaremos mais sobre o conceito de "números sonoros", uma analogia com a expressão "números musicais" que, em síntese, se refere a momentos nos quais o filme concede um extenso tempo de tela e de alto-falantes para cenas nas quais não há diálogos, entrevistas, narração ou música (em um sentido tradicional), mas nas quais algum outro aspecto sonoro (tiros, reza) está em relevo. 
Vozes da guerra, cantos de amor: um documentário-balada sobre meninos soldados

\begin{tabular}{|c|c|c|}
\hline \multicolumn{3}{|c|}{ TERCEIRO BLOCO } \\
\hline 13. Estribilho & Canción de amor autóctone & $18: 10$ a $19: 42$ \\
\hline 14. Estrofe & Entrevista com mulher miskito & $19: 43$ a $24: 54$ \\
\hline 15. Estrofe & O filho da mulher & $24: 55$ a $26: 52$ \\
\hline 16. Estrofe & Treinamento militar das crianças: ordem unida & $26: 53$ a 28.37 \\
\hline \multicolumn{3}{|c|}{ QUARTO BLOCO } \\
\hline 17. Estribilho & $\begin{array}{l}\text { Instrução militar: "número sonoro" das metra- } \\
\text { lhadoras }\end{array}$ & $28: 38$ a $32: 20$ \\
\hline 18. Estrofe & Entrevistas com pequenos soldados & $32: 21$ a $35: 44$ \\
\hline 19. Estrofe & Entrevista com instrutor & $35: 45$ a $38: 11$ \\
\hline \multicolumn{3}{|c|}{ QUINTO BLOCO } \\
\hline 20. Estribilho & $\begin{array}{l}\text { "Número sonoro" da reza coletiva dos pequenos } \\
\text { soldados }\end{array}$ & $37: 24$ a $38: 10$ \\
\hline 21. Estrofe & Denis Reichle y los niños soldado. & $38: 11$ a $41: 11$ \\
\hline 22. Estrofe & Instrução militar & $41: 12$ a $42: 27$ \\
\hline \multicolumn{3}{|c|}{ FINAL } \\
\hline 23. Estribilho & $\begin{array}{l}\text { Pequeno soldado canta "Flor de mi vida" ( } d a \\
\text { capo) }\end{array}$ & 42:28-44:00 \\
\hline
\end{tabular}

Em uma primeira mirada, fica evidente que o filme não segue rigorosamente o modelo estrofe - 3 estribilhos. No primeiro e segundo blocos temos 5 estrofes/cenas, enquanto que no terceiro boloco temos 3 e apenas 2 no quarto e no quinto. Observando, contudo, o modo como os "números musicais e sonoros" estão organizados na linha do tempo do filme, nos arriscamos a defender que o filme presta tributos a uma outra característica definidora da balada: a organização estribilho-estrofe em um regime simétrico.

De acordo com Fowler (1968: 68), o elemento estrutural mais importante da balada é a simetria. É possível dizer que Balada do pequeno soldado é um documentário simétrico? Até certo ponto, sim. A correlação analítica estrofe/cena; estribilho/canção, assim como a duração da primeira parte do filme, dão conta de um bom grau de regularidade. A segunda e terceira canções se iniciam exatamente 9 minutos depois do início da canção anterior. Se levarmos em consideração somente as canções, é fato que essa regularidade se dilui depois da terceira canção. No entanto, cabem aqui algumas reflexões sobre a "musicalidade" da trilha sonora em cenas que estão localizadas em pontos estratégicos (simétricos?) do filme.

Cerca de 8 minutos após a exposição da 3a canção, tem início o segmento em que o filme nos apresenta aos instrutores dos pequenos soldados. Vemos os instrutores em ação, comandando exercícios de ordem unida. Como é comum neste tipo de treinamento militar, os instrutores estabelecem o ritmo do treino 
entoando frases de comando que devem ser respondidas pela tropa. Esses padrões rítmicos responsoriais, associados aos movimentos corporais e às batidas dos pés no chão, operam como "protomúsica" e "protodança", um (proto) bailado audiovisual. Esse pulso rítmico vocalizado é ouvido em primeiríssimo plano sonoro por cerca de um minuto e vinte segundos, quando desce para plano-de-fundo para dar lugar à voz do narrador, que nos informa que os instrutores pertenceram à antiga Guarda Nacional de Somoza e inicia a transição para a cena seguinte: o treinamento de tiro, durante o qual a trilha sonora é dominada pelo rugido (a)rítmico das metralhadoras. Cerca de 8 minutos após o fim da protomúsica das metralhadoras, a trilha sonora nos oferece um ponto de respiração: a beleza da polifonia e da polirritmia das vozes das crianças que entoam em conjunto (mas sem sincronismo), o que nos parece ser uma reza na língua miskito. Há aqui também um encanto sensorial que cria um forte contraste expressivo com a espécie de desconforto espectatorial que o rugir das metralhadoras do "número sonoro" anterior provoca. Observando a trilha sonora sob essa perspectiva, ou seja, ouvindo a musicalidade inerente aos sons recém descritos, defende-se aqui que o filme tem como estribilho "números sonoros" compostos ora por canções, ora por comandos vocais responsoriais, sons de ritmos corporais, tiros e rezas.

Sem dúvida, trata-se de um uma estrutura audiovisual que alterna estribilho ("números sonoros") com estrofes (diálogos, entrevistas, voz over). É verdade que não se vê nesse filme o mesmo rigor formal de vínculo com um modelo composicional que pode ser observado no Sonata de outono, de Bergman, mas a análise revela que a montagem organiza no tempo o que aqui consideramos como estribilho e estrofe de um modo proporcional. Ainda que não haja uma aderência estrita ao formato "estribilho - 3 estrofes", característico da balada, acreditamos que isso não interdita afirmar que o modelo simétrico desta tenha sido utilizado como texto-fonte, desde que consideremos que a mutação do modelo em filme tenha desfrutado de liberdade.

\section{As vozes do real. Diálogos, plurilinguismo e tradução}

Ainda que a música tenha uma grande importância neste documentário, é importante ressaltar que, de acordo com a tradição herzogiana discutida inicialmente nesse texto, acima dela se situa sempre a voz. Como aponta Michel Chion "el sonido en el cine es mayoritariamente vococentrista" (1993: 14), isto é, a voz sempre se destaca e sobrepõe aos demais sons, como se fosse o instrumento principal de uma orquestra. Por esta razão, o som fônico, compreendido pelo diálogos e vozes em off e over costuma ser gravado com a máxima clareza possível. "El diálogo, el transmisor de la información de la historia, se 
Vozes da guerra, cantos de amor: um documentário-balada sobre meninos soldados

graba y reproduce por lo general con el fin de que tenga la máxima claridad. Las frases importantes no tendrán que competir con la música o con el ruido de fondo" (Bordwell, 1995: 298). A seguir, vamos descrever três funções da voz que permitem compreender, em maior medida, as estratégias criativas de Balada do pequeno soldado: a função dialógica, a função plurilingüística e a função tradutora. A partir destas funções, construiremos uma interconexão com alguns aspectos da teoria decolonial, tais como o diálogo de saberes (Castro Gómez), a decolonização da linguagem (Veronelli) e o perspectivismo etnográfico (Viveiros de Castro).

Em primeiro lugar, encontramos nesse documentário de Herzog uma função dialógica. Alguns pesquisadores apontam que Herzog dialoga com o real e que o resultado desse diálogo é a película final (Álcala, 2013: 114). Por meio dela, esse diálogo seria uma forma de "interrogar a lo real en el marco de una relación subjetiva con lo que filma" (González, 2013: 20). Em Balada do pequeno soldado, observamos como o jornalista Denis Reichle, coautor do filme, interroga e dialoga, ao longo do documentário, com diferentes miskitos sobre o conflito com os sandistas: uma senhora idosa que narra como os sandinistas a roubaram; um soldado de Sang Sang que conta como eles cortaram suas palmeiras e incendiaram sua casa; outra mulher que narra como os amarraram e mantiveram presos no pátio da Igreja; alguns meninos que relatam como mataram suas famílias; un instrutor que fala sobre a importância da luta contra os sandinistas e que elogia la valentia dos meninos soldados; outro instrutor que explica a necessidade da lavagem cerebral para a luta; e, finalmente, os meninos aos quais se pergunta sobre a guerra, a morte e o medo. Na última cena, Denis Reichle ainda conta como, ainda jovem, ele também esteve envolvido na luta com os russos durante a II Guerra Mundial, destacando como a situação dos meninos soldados lhe recorda sua própria infância. Se estabelece, assim, uma espécie de processo de transferência: o jornalista alemão explica como, aos 13 anos, lhe disseram que teria que lutar por sua pátria, assim como fazem com os pequenos soldados miskitos. No final dessa cena, Reichle conclui que já vê esses meninos mortos. Este modo de abordar a construção do diálogo com os miskitos - com os Outros -, elude o a priori do roteiro. Em seus documentários, Herzog não parte de um roteiro que defina um caminho a percorrer. O diálogo é a crise do roteiro.

Contudo, esta forma de compreensão do real por meio do diálogo se situa distante da concepção de verdade do cinéma vérité, pois não pretende acessar o real na mesma linha de trabalho exercida por este. Em Minnesota Declaration: Truth and Fact in Documentary Cinema, Herzog afirma: "Por força de declaração, o chamado Cinéma Vérité é desprovido de verdade. Alcança uma verdade 
meramente superficial, a verdade dos contadores" (Herzog, 2002: 301; tradução nossa). Dessa forma, o cineasta alemão declara que o cinéma vérité forja uma verdade superficial que é preciso transcender, mas ao mesmo tempo considera que "é possível chegar a uma camada mais profunda da verdade: uma verdade poética, extática, que é um mistério" (Herzog, 2010b: 6; tradução nossa). Uma verdade nas antípodas da verdade científica e pretensamente objetiva dos paladinos do cinema direto, e que tem como finalidade submergir em uma verdade mais poética e mais política. A imagen não pode ser asséptica, tem que conter beleza e ser crítica. O própio Herzog reconhece que "não devemos ser uma mosca na parede, não vamos ser a câmera de vigilância de um banco. Temos que ser a vespa que pica" (Herzog, 2013:13; tradução nossa).

Como então interpretar o uso da voz, da palavra e do diálogo com aqueles que são diferentes de nós? De que maneira afrontamos a relação entre a voz e a verdade? Há uma ou várias verdades? Estas questões, ainda que relevantes para pensar o uso da palavra no cinema documentário, também o são para teorizar sobre a importância do diálogo a partir das coordenadas da semiótica e da teoria decolonial. Desse modo, podemos relacionar as estratégias de apreensão do real aqui discutidas com o dialogismo de Bakhtin, quando este afirma que "el sentido descubre sus profundidades al encontrarse y al tocarse con otro sentido, un sentido ajeno" (Bakhtin, 1999: 352). Uma busca pelo outro marcou sem dúvida o afã criativo deste cineasta-viajante que é Herzog.

De modo semelhante, também o conceito de intertextualidade dos semiólogos Roland Barthes e Julia Kristeva pode ser operativo para a interpretação do modus operandi desse cineasta alemão. Julia Kristeva diferenciava o discurso monológico do dialógico, definindo este último como "una lógica de la distancia y de relación entre los diferentes términos de la frase o de la estructura narrativa, que indique un devenir" (Kristeva, 2001: 32).

Esta ideia parece ajustar-se aos documentários de Herzog que, como no caso aqui analisado, costumam configurar suas narrativas a partir do diálogo. Se trata de dialogar com o real em um esforço de comprensão que coloca em crise o monólogo da ciência e do cinema espetáculo. Tanto o cinema como a ciência ocidental são profundamente ideológicos e se encontram ensimesmados, sem muita vontade de se abrir a outros saberes, nem estabelecer e traçar uma conexão intertextual.

Em Balada do pequeno soldado, observa-se, sobretudo por meio do uso da voz, uma função dialógica rebelde, resistente. Uma voz que incorpora outras vozes e que, por isso, permite que o cinema seja abordado a partir da ótica dos estudos decoloniais. Podemos defender, com Castro Gómez, que não pode haver diálogo sem "permitir un intercambio cognitivo entre la ciencia occidental 
y formas posoccidentales de producción de conocimientos (...) el diálogo de saberes sólo es posible a través de la decolonización del conocimiento y de la decolonización de las instituciones productoras o administradoras del conocimiento" (Castro Gómez, 2007: 88). O conceito de diálogo de saberes é útil para pensar o cinema documentário, na medida em que permite não apenas a fuga dos princípios etnocêntricos, como também fornece o espaço para conhecer o outro a partir de suas próprias epistemologias. Nesse sentido, a palavra no cinema documentário pode servir para conhecer o outro a partir dele próprio.

Em segundo lugar, pretendemos agora dar conta das singularidades linguísticas do outro para identificar a função plurilinguística desenvolvida por Herzog. Essas singularidades e essas línguas distintas que habitam o filme, parecem despertar a curiosidade do cineasta, sempre ávido por novidades e à caça de outras imagens, sons e línguas. Em Toyko-Ga (Wenders,1985), ele afirma:

Lo que pasa simplemente es que solo quedan pocas imágenes. Cuando miro aquí afuera, todo está edificado, las imágenes no tiene espacio. Uno tiene que excavar como un arqueólogo para encontrar algo en este paisaje herido. Necesitamos imágenes que correspondan a nuestro estado de civilización y a nuestro profundo interior. Me iría a Marte si fuera para encontrar imágenes puras, ya que en esta tierra no es fácil encontrarlas. (Herzog, 1985).

Sem dúvida, Herzog está sempre atravessando os estratos do real em busca do que acredita ser uma imagem pura, um som puro. Este som puro da língua parece ser o que de certo modo busca entre os indios miskitos. Uma pureza sonora que atravessa seu ouvido e que podemos afirmar ser altamente fenomenológica, já que sempre se trata de suspender o universo das ideais preconcebidas para escutar. De fazer epojé para encontrar o próprio som do outro. É preciso considerar, em outro sentido, que apesar de forjar seu filme a partir de uma multiplicidade de voces, Herzog sustenta seu apoio à causa dos indígenas. Vale lembrar que, por conta desse filme, foi tachado de antisandinsita e de lacaio da CIA (Navas, 2015: 117), ainda que deixe claro que sua intenção, não seja criticar a Frente Sandinista de Liberação Nacional. Sua posição era pró-indígena (Weinrichter, 2007: 128), ou seja, o filme trata muito mais de uma reivindicação do indigenismo do que de um debate sobre o conflito na Nicarágua a partir da perspectiva da Guerra Fria.

É por conta disso que este filme se abre ao outro indígena, à sua língua, adotando como estratégia o uso de uma função plurilinguística no marco do documental. Para Herzog, como já assinalamos, a verdade sempre parte de uma situação dialógica. No entanto, esta situação supõe um esforço para entrelaçar as diferents vozes em un relato polifônico in progress. Una polifonia 
marcada pelos diversos idiomas que conformam os enunciados do filme: espanhol, inglês, alemão, miskito. Ouvimos entrevistas e canções em espanhol e em miskito, uma entrevista em inglês, e toda a voz over em alemão. Há, portanto, uma multiplicidade de vozes que compartilham o espaço da banda sonora. Uma multiplicidade fônica que Chion definiu como "poliglotía o empleo de una lengua extranjera: algunas películas, necesariamente aisladas, han pretendido relativizar la palabra utilizando una lengua extranjera, no entendida por la mayoría de sus espectadores, o bien mezclando idiomas diversos, lo que viene a ser relativizar las lenguas recíprocamente" (Chion, 1993: 139).

Podemos interpretar essa poliglotia a partir teoria decolonial da linguagem proposta por Gabriela A. Veronelli. A filósofa lança luz sobre os processos de colonailidade linguística que estão ligados ao racismo inerente ao sistema colonialidade/modernidade:

El problema que plantea la colonialidad del lenguaje es el problema de la relación raza/lenguaje (...) Desde dentro, el enorme aparato epistémico-ideológico de la modernidad permite a la imaginación colonial presuponer a los colonizados-colonializados como seres menos-que-humanos, expresiva y linguísticamente. (Veronelli, 2015: 47-48).

Em outras palavras, a colonialidade constrói ideologicamente a inferioridade da linguagem indígena, e, por essa razão, a decisão de deixar que os miskitos falem em sua própria língua, como faz Herzog, aponta para um estímulo decolonial. O que se fez durante a colonização foi justamente naturalizar a língua do conquistador, fazendo dela a única "verdadeira", ao passo que se fazia do indígena um ser sem linguagem e, consequentemente, aquele com o qual não é possível a comunicação:

Dada la imposibilidad de ver al colonizado como un interlocutor (...) no hay una disposición comunicativa por parte del colonizador-colonializador, sordo a toda posibilidad de sentido que salga de la boca del colonizadocolonializado. En este caso, difícilmente se puede hablar de un 'vivir juntos' o 'vivir en compañía de otros' - que es lo que finalmente significa "conversar'." (Veronelli, 2015: 54).

O filme de Herzog e Reichle, pelo contrário, pretende construir um diálogo com eles, um ponto de encontro. Desse modo, a crítica à colonização da linguagem reivindicada por Veronelli resulta interessante para se pensar uma voz plural e não etnocêntrica no campo do cinema documental.

Em terceiro e último lugar, vamos nos deter no uso da função tradutora en Balada do pequeno soldado. Logicamente, esta função está relacionada com as duas anteriores, pois para que haja diálogo entre pessoas portadoras de línguas diferentes é imprescindível un ato de tradução. Vejamos dois exemplos de tradução em cenas distintas do filme. Na primeira, escutamos como uma 
Vozes da guerra, cantos de amor: um documentário-balada sobre meninos soldados

mulher utiliza (voz in) a língua inglesa, até que, em um momento do relato, ela chega a uma palavra que desconhece. Por esta razão, retorna a sua língua miskito e pronuncia pialka. Neste momento, a voz over intervem e se sobrepõe a ela para nos dizer o significado dessa palabra, agora em alemão: "máquina de costura". Na segunda cena em questão, outra mulher (voz in) narra, em língua miskito, como o exército sandinista lhe tomou seus filhos. Ao terminar seu relato, este é traduzido em espanhol por um personagem que aparece no plano diegético, ao mesmo tempo em que, no plano extradiegético, a voz over, em alemão, se sobrepõe. No primeiro caso, temos uma sobreposição da língua alemã (voz over) sobre a inglesa (voz in) e, no segundo caso, uma sobreposição sobre a língua espanhola (voz in). É importante ressaltar que as vozes diegéticas são as vozes originais, aquelas que aportam credibilidade:

la voz in (...) la opción por la voz en campo es la necesidad de hacer corresponder las palabras pronunciadas con el movimiento de los labios: problema bastante menos banal de lo que parece, puesto que incide inmediatamente en la credibilidad de aquello que está ante nosotros. Lo advertimos limpiamente en los films doblados: cambiando la lengua, además de cambiar el tono, o el ritmo de la voz (...) nos arriesgamos siempre a una ligera pero sensible separación entre la palabra que se oye y la palabra que se ve pronunciar (...) la «toma directa» comporta casi siempre un efecto de verdad (...) porque el micrófono forma casi un solo objeto con la cámara, y un acercamiento o un alejamiento de esta última determina un acercamiento o alejamiento análogo de la voz. (Casetti \& Di Chio, 1991: 101).

Quando a voz over em língua alemã se sobrepõe, ela sempre o faz sobre o inglês ou espanhol, nunca sobre a língua miskito. Tal sobreposição forja uma transformação do tom, ritmo e timbre da qual pode derivar um câmbio semântico. Na segunda cena, assistimos a um encadeamento de traduções, a uma "tradução da tradução". Ainda que a voz in carregue consigo um "efeito de verdade", é preciso dizer que este se vê simulado e traído no ato da tradução. E, nesse caso, duplamente. Primeiro, pela tradução do miskito para o espanhol e, depois, pela tradução deste para o alemão. $\mathrm{O}$ ato de tradução da palavra original para sua versão em outra língua sempre implica numa traição, como nos lembra a célebre expressão traduttore, traditore. Ainda assim, é preciso notar que cada uma dessas traduções apresenta suas singularidades. No primeiro caso, do miskito ao espanhol, a tradução é encadeada e diacrônica, enquanto que, no segundo caso, do espanhol ao alemão, é simultânea e sincrônica, o que implica que a substância fônica da voz over em alemão apague e submeta a voz in em espanhol.

Contudo, apesar da tradução ser um modo de afastamento do real, não podemos esquecer que é, igualmente, uma ferramenta que possibilita o entendimento. Nesse sentido, o jornalista Denis Reichle é aquele que exerce o papel 
de catalisador comunicativo no filme: Herzog "utilizó al periodista Dennis Reichle, que figura como co-director de la película y que ejerció de interlocutor con los niños y demás personas que aparecen" (Navas, 2015: 117). Um catalisador, justamente, porque conhecia a língua espanhola e a alemã. Mas também há um outro tradutor que o acompanha, na medida em que conhece, simultaneamente, a língua dos miskitos e a espanhola.

A tradução permite, assim, incluir a perspectiva do outro. Eduardo Viveiros de Castro, a partir do marco teórico da antropologia decolonial, atualizou o conceito filosófico de "perspectiva" para pensar as sociedades indígenas ameríndias. Para estudar os indígenas, segundo Viveiros de Castro, é imprescindível colocar-se em seu lugar, ver a partir de onde se colocam: "el perspectivismo amerindio comienza por la afirmación doblemente contraria: 'el otro existe, luego piensa'." (Viveiros de Castro, 2013: 80). Contudo, se o outro pensa, indefectivelmente, seu pensamento tem que ser um pensamento outro. É este pensamento outro que caracteriza o perspectivismo:

"Perspectivismo" fue un rótulo que tomé prestado del vocabulario filosófico moderno para calificar un aspecto muy característico de varias, sino todas, las cosmologías amerindias. Se trata de la noción, en primer lugar, de que el mundo está poblado por muchas especies de seres (además de los humanos propiamente dichos) dotados de conciencia y de cultura y, en segundo lugar, de que cada una de esas especies se ve a sí misma y a las demás especies de un modo bastante singular: cada una se ve a sí misma como humana, viendo a las demás como no humanas, esto es, como especies de animales o de espíritus. (Viveiros de Castro, 2013: 36).

É possível conectar esta ideia sobre o perspectivismo com o discurso audiovisual do nosso filme-objeto. Há na obra uma clara intenção de oferecer ao espectador as vozes dos miskitos e de seus pequenos soldados. No entanto, narrativa e poeticamente, essas vozes competem com uma voz de autoridade, materializada no filme pela voz over de Herzog.

\section{A vespa que pica o coração do real}

No âmbito dos estudos sobre aspectos sonoros nos documentários, de maneira geral, uma dimensão cognitiva, centrada no conteúdo das falas em suas tensões, distensões, fissuras e rupturas em relação ao "real", são objetos e unidades de análise que costumam deixar pouco espaço para reflexões acerca das sensações e, especialmente, dos sentimentos que, muitas vezes, são um propósito importante da obra. É justamente nessa dimensão que as músicas que fazem parte da peça documental operam. (Maia, 2012).

Para Bill Nichols (2005), a sensação de realismo fotográfico, de revelação do que a vida tem a oferecer quando é filmada com simplicidade e sinceridade, 
não é, de fato, uma verdade, mas sim um estilo. Dentro dessa perspectiva, Nichols nos fala de dimensões psicológicas e emocionais de vínculo com a realidade. Realismo emocional, para ele,

diz respeito à criação de um estado emocional adequado no espectador. Um número musical exótico pode gerar um sentimento de exuberância no público, embora haja pouca profundidade psicológica nos personagens e o cenário seja obviamente fabricado. Ainda assim, reconhecemos uma dimensão realística na experiência: é como outras experiências emocionais que tivemos. A emoção em si é familiar e sentida de maneira genuína. (Nichols, 2005: 128).

Já no entender de alguns documentaristas, atingir a emoção do espectador é a função principal do filme documental. No documentário Capturying reality (Pepita Ferrari, 2008), Kim Longinotto considera que "rather then telling people what to think or, you know, they are learning a lesson, we're taking them into an emotional experience". No mesmo filme, Scott Hicks diz que o documentário é "an emotional medium. It's not a medium of intellect and intelectual discourse. It's about engagement and emotion." A análise das canções que operam em a Balada do pequeno soldado, nos induz à conclusão de que elas estão em cena como "números musicais exóticos" como disse Nichols, que visam o engajamento do espectador em uma experiência emocional - como disseram Longinotto e Hicks - de realidade.

Como foi visto, apostamos aqui que, em sua dimensão formal, a obra se constitui sobre um modelo estribilho / estrofe, segundo o qual, na função de estribilho estão os "números musicais" e os "números sonoros". Ouvindo o filme sob essa perspectiva, nos foi possível inferir a presença de uma instância realizadora que deseja não somente revelar uma realidade trágica e ser a vespa que pica o coração do espectador, mas também produzir um efeito de encantamento pela ordem da sua própria estrutura, organizada em um jogo intertextual com a balada medieval.

Já as falas dos miskitos, dos instrutores, de Herzog e de Reichle contribuem para a configuração de um peculiar acesso ao real por meio de 3 funções detectadas na nossa análise. A função dialógica permite a interrogação da realidade a fim de trazer à tona outras "verdades" para além daquelas que o cinéma vérité e o cinema direto buscam revelar. A voz, nesse sentido, é também um lugar de encontro com a alteridade. De fato, nota-se claramente um esforço de revelar a condição trágica daquelas crianças, mas também de nos fazer ouvir as vozes dos miskitos. A função plurilinguística decorre da inquietude dos realizadores para gravar "outras" vozes. A ideia parece ser forjar uma trama poliglota, uma multiplicidade de enunciados em diferentes idiomas. Finalmente, identificamos a função tradutora, aquela que realmente torna possível o diálogo entre 
pessoas que falam diferentes idiomas e permite dar conta, em certa medida, da perspectiva do outro.

Juntando as peças deste quebra-cabeças sonoro, isto é, devolvendo integridade ao que foi decomposto no processo analítico, é possível entender os sons de Balada do pequeno soldado como eventos de uma partitura polifônica complexa, composta por vozes, ruídos e canções que conspiram a favor de uma particular decodificação poética da realidade (o que, como vimos na introdução deste artigo, parece ser uma constante nas trilhas sonoras da obra documental de Herzog). Para muito além do registro dos sons que emanam do mundo filmado, o que se percebe é que a matéria sonora daquela realidade está organizada como uma composição de muitas "musicalidades": a musicalidade das canções cursi mexicanas, dos cantos autóctones dos miskitos, do cântico católico, dos tiros, da reza e das falas em miskito, espanhol, inglês e alemão.

Dessa forma, para muito além de um posicionamento político em relação a uma situação de conflito na Nicarágua, Herzog e Reichle nos contam e cantam uma balada triste sobre o sequestro da infância e da vida de crianças como aquela que nos foi apresentada na abertura do filme cantando, com sua metralhadora, a dor da ausência dos ojitos dormilones de la niña de la mochila azul.

\section{Referências bibliográficas}

Alcalá, F. (2013). El cine de lo real: la huella de Alexander Kluge, Werner Herzog y Harun Farocki. In J. M. Català (ed.), El cine de pensamiento: formas de la imaginación tecno-estética (pp. 105-119). Valencia: Servei de Publicacions.

Ames, E. (2012). Ferocious reality: documentary according Herzog. Minneapolis - London: University of Minnesota Press.

Bajtín, M. (1999). Estética de la creación verbal. México: Editorial XXI.

Bordwell, D. R. (1995). El arte cinematográfico: una introducción. Barcelona: Paidós Ibérica.

Casetti, F. \& Di Chio, F. (1991). Cómo analizar un film. Barcelona: Paidós.

Castro-Gómez, S. (2007). Decolonizar la universidad. La hybris del punto cero y el diálogo de saberes. In El giro decolonial. Reflexiones para una diversidad epistémica más allá del capitalismo global (pp. 79-91).

Chion, M. (2011). A audiovisão. Lisboa: Texto \& Grafia.

Corrigan, T. (org.) (1986). The films of Werner Herzog: between mirage and history. New York and London: Methuen. 
Deleuze, G. (1985). Cinema 1: A imagem-movimento. São Paulo: Brasiliense.

Fowler, D. C. (1968). A literary history of the popular ballad. Michigan: Duke University Press.

Friedman, A. B. (1962). The ballad revival: studies in the influence of popular on sophisticated poetry. Chicago: The University of Chicago Press.

González, L. (2013). Werner Herzog: el documental como indagación fenomenológica. Revista Question, 1(40).

Herzog, W. (2002). The Minnesota Declaration: Truth and fact in documentary cinema. In Herzog on Herzog, (pp. 301-302).

Herzog, W. (2010). Sobre lo absoluto, lo sublime y la verdad extática. Trad. y notas de Ricardo Ibarlucía. El Ángel Exterminador. Revista digital de cine (19).

Herzog, W. (2010). Herzog en el San Martín. Revista Ñ, Buenos Aires, 22 de enero de 2010.

Herzog, W. (2013). Los 10 mandamientos de Werner Herzog. Haciendo Cine, 5 de septiembre de 2013. Disponible en: www.haciendocine.com.ar/cont ent/los-10-mandamientos-de-werner-herzog

Kristeva, J. (2001). Semiótica 1. Madrid: Fundamentos.

Maia, G. (2012). Aspectos da música no documentário brasileiro contemporâneo: algumas reflexões sobre o fazer e o pensar. Doc On line, 12: 100126, agosto de 2012. Disponível em www.doc.ubi.pt/12/dt_guilherme_m aia.pdf

Miyares, J. R. V. (ed.). (2009). Baladas de Robin Hood, vol. 3. Ediciones AKAL.

Nagib, L. (1991). Werner Herzog: o cinema como realidade. São Paulo: Estação Liberdade.

Nagib, L. (2011). World cinema and the ethics of realism. Londres : Continuum Books.

Navas Valdés, B. (2015). El paisaje como elemento dramático en la obra de Werner Herzog. Doctoral dissertation, Universidad Complutense de Madrid.

Nichols, B. (2005). Introdução ao documentário. Campinas: Papirus.

Prager, B. (2007). The cinema of Werner Herzog: aesthetic ecstasy and truth. London and New York: Wallflower press.

Rojas, M. R. (2016). León de Greiff y su asimilación de la poesía medieval. Estudios de literatura colombiana, (38): 13-37. 
Veronelli, G. A. (2015). Sobre la colonialidad del lenguaje y el decir. Universitas Humanística, (81): 33-58.

Viveiros de Castro, E. (2013). La mirada del jaguar. Introducción al perspectivismo ameríndio. Buenos Aires: Tinta y limón.

Weinrichter, A. \& Díaz, N. G. (eds.). (2007). Caminar sobre hielo y fuego: los documentales de Werner Herzog. Ocho y Medio.

\section{Filmografia}

Balada do pequeno soldado (1984), de Werner Herzog e Denis Reichle.

Fata Morgana (1971), de Werner Herzog.

Fitzcarraldo (1982), de Werner Herzog.

O diamante branco (2004), de Werner Herzog.

O Homem urso (2005), de Werner Herzog.

O país do silêncio e da escuridão (1971), de Werner Herzog.

Os sinos do abismo: fé e superstição na Rússia (1993), de Werner Herzog.

Sonata de outono (1978), de Ingmar Bergman.

Wodaabe: herdsmen of the sun (1989), de Werner Herzog.

Tokio Gaga (1985) de Wim Wenders. 